\title{
Kirkpatrick Model Evaluation of Accelerated Second-Degree Nursing Programs: A Scoping Review
}

\author{
Hyejung Lee, PhD, RN; and Youngkwan Song, PhD, RN
}

\begin{abstract}
Background: This scoping review examined the outcomes of accelerated second-degree baccalaureate and master of nursing programs using the Kirkpatrick four-level model. Method: A systematic search of four major scientific databases identified 15 articles meeting study inclusion criteria. The articles were assessed for educational outcomes, and extracted data were organized according to the fourlevel Kirkpatrick model consisting of reaction, learning, behavior, and results. Results: Both second-degree baccalaureate and master of nursing program students showed strong academic achievement, high employment rates, and high program satisfaction but reported lack of perceived preparedness for a clinical position. No studies evaluated the long-term impacts of the programs on graduates' clinical practice or patient outcomes. Conclusion: Accelerated second-degree nursing programs quickly and efficiently produce licensed nurses. The care provided by the graduates of these accelerated programs needs to be investigated in both short- and long-term to better determine overall program effectiveness. [J Nurs Educ. 2021;60(5):265-271.]
\end{abstract}

Dr. Lee is Associate Professor, Mo-Im Kim Nursing Research Institute, College of Nursing, Yonsei University, Seoul, Korea; and Dr. Song is Postdoctoral Research Associate, College of Nursing, University of Illinois at Chicago, Chicago, Illinois.

This study was supported by a faculty research grant funded by the Yonsei University College of Nursing.

The authors thank Mr. Jon S. Mann for his editorial assistance.

The authors have disclosed no potential conflicts of interest, financial or otherwise.

Address correspondence to Youngkwan Song, PhD, RN, College of Nursing, University of Illinois at Chicago, Illinois, 845 South Damen Avenue, Room 745, Chicago, IL 60612; email: ysong202@gmail.com.

Received: June 22, 2020; Accepted: October 7, 2020

doi:10.3928/01484834-20210420-05
$\mathrm{T}$ The nursing shortage has created serious concerns in many countries (Organisation for Economic Cooperation \& Development [OECD], 2017). A rapidly aging population with complex chronic diseases and new global infectious diseases has exacerbated the demands placed on the nursing workforce in health care systems (Ding et al., 2016; Jan et al., 2018). Well-trained nurses are critical to delivering safe care and maintaining quality outcomes in hospitals. However, the current number of active nurses falls significantly short of demand, and clinically competent nurses are needed now more than ever (OECD, 2017). To address this issue, shorter but upgraded nursing programs have received interest, and accelerated programs for students with bachelor's degrees in other disciplines have gained momentum.

In the 1970s, an accelerated baccalaureate nursing (ABSN) program was first introduced in the United States. This fasttracked program allowed students to complete a nursing curricula in approximately half of the time required for traditional baccalaureate nursing (TBSN) programs (American Association of Colleges of Nursing [AACN], 2019). Students who enroll in the ABSN programs tend to be motivated to complete the nursing curriculum with good academic standing and to pass the National Council Licensing Examination for Registered Nurses (NCLEX-RN $^{\circledR}$ ) (Kaddoura et al, 2017; Moe et al., 2009). Nurse managers' evaluations of ABSN graduates (Rafferty \& Lindell, 2011) indicated they did not differ from TBSN graduates in clinical competency, and managers valued ABSN graduates' professional socialization and the quality of care they delivered based on their experience in other disciplines.

More than 280 ABSN programs currently are offered in the United States after a dramatic proliferation during the past three decades. Three years after the ABSN programs began, an accelerated master of science in nursing (AMSN) program was launched in the United States. The AMSN programs differ from ABSN programs in terms of awarding the master's degree upon completion of the curriculum and having a longer curriculum of 3 years. Students in AMSN programs spend the first year in a prelicensure curriculum taking BSN courses and the last 2 years taking courses at the master's level (AACN, 2019). However, many different models of AMSN programs exist under vary- 
ing program names and educational philosophies (Mark et al., 2019). Jackson and Marchi (2020) found that $42 \%$ of AMSN programs reviewed educated students to prepare them for the clinical nurse leader role, and $21 \%$ of programs prepared students for the advanced practice nurse (APN) role. The authors also recommended that nurse educators redesign the curriculum for pursuing an APN career to be qualified for the Doctor of Nursing Practice degree and that they reevaluate outcomes of students to ensure their competence to enter practice. More than 64 AMSN programs are now offered, and 13 more programs are taking shape in the United States (AACN, 2019).

Besides the United States, western countries such as Australia and Canada have incorporated ABSN and AMSN program models into their traditional nursing educational systems with positive educational outcomes (Cantlay et al., 2017; Ezer et al., 1991; Roberts et al., 2001). In addition, in 2019, South Korea temporarily increased its quota for ABSN program students by $30 \%$ to address the demand for RNs; furthermore, nursing education innovations such as AMSN programs are being considered to prepare students to assume leadership and educational roles in clinical settings (Ministry of Health and Welfare, 2018). Given the largely successful history of ABSN and AMSN programs to date and the need for innovative, full-scale implementation of such programs worldwide, systematic program evaluation is necessary to acquire constructive feedback and demonstrate their effectiveness in terms of educational outcomes.

The Kirkpatrick model (Kirkpatrick \& Kirkpatrick, 2016) often is used as a means of categorizing and evaluating the outcomes of educational and training programs (Dorri et al., 2016; Heydari et al., 2019; Jones et al., 2020). In the Kirkpatrick model, learning outcomes of programs are categorized using four levels: reaction, learning, behavior, and results. When the model's four levels of evaluation were first introduced, there was no shared language or efficient means of communicating the meaning or methods of evaluation. In response, the authors developed a logical framework to analyze program outcomes and effects from the perspectives of individual or organizational performance (Isyanto et al., 2020). Despite the advantages of the model, no studies to date have applied it to evaluate the educational outcomes of accelerated second-degree nursing programs. Furthermore, although ABSN and AMSN programs share matriculation prerequisites, standards, and fast-track curricula, many studies have been limited to either reporting program-specific educational outcomes or comparing the outcomes of accelerated and traditional programs without an evaluative framework (Payne \& Mullen, 2014).

To help fill these research gaps, this scoping review evaluated the educational outcomes of both accelerated second-degree program models based on the Kirkpatrick (2016) model. The findings provide meaningful insights for individuals, nursing educators, policy makers, and other stakeholders considering attending or implementing such programs.

\section{METHOD}

This study used a scoping review method. This approach is appropriate to map the relevant literature in a relatively new area of interest because no literature exists to compare these two programs directly. The review followed the five-stage framework recommended by Arksey and O'Malley (2005), which uses rigorous steps of transparency that both support duplication of the search and enhance the reliability of the results. These stages include: (1) determining the research questions, (2) identifying relevant studies, (3) selecting studies, (4) compiling the data, and (5) summarizing the data and reporting the results.

\section{Determining the Research Questions}

The main purpose of this review was to examine ABSN and AMSN program outcomes and categorize those outcomes into the four levels of the Kirkpatrick (2016) model. To ensure that a full range of studies was captured, the following two research questions were used to guide the search:

1. What educational outcomes of ABSN and AMSN programs were reported in the literature?

2. What levels of the Kirkpatrick model were evaluated?

\section{Identifying Relevant Studies}

When identifying studies using the approach outlined by Arksey and O'Malley (2005), a wide definition was used to obtain the greatest possible coverage of the literature on ABSN and AMSN programs and their educational outcomes. A university librarian was consulted to refine the key search terms and identify adequate databases. Nursing subject headings and Boolean operators were used to focus, broaden, and combine literature searches. The key search terms were as follows: "outcomes of education" OR "outcome assessment" OR "outcomes" OR "educational outcome" OR "learning environment evaluation") AND ("accelerated program" OR "direct entry program" OR "entry program" OR "second-degree program" OR "education, nontraditional" OR "education, masters" OR "education, baccalaureate") AND nurse.

Inclusion and exclusion criteria were established to make the identification of primary evidence as comprehensive as possible. Inclusion criteria required studies that were written in English, were peer-reviewed, involved students or graduates of either ABSN or AMSN programs, and reported on the outcomes of the programs using a quantitative and mixed-methods design. Exclusion criteria prohibited review articles, qualitative research, studies that focused on attributes of students or graduates of ABSN or AMSN programs (e.g., learning styles or strategies and socialization), and studies of other types of nursing programs such as RN to Bachelor of Science in Nursing (BSN). No date limits were applied to the search, and the electronic databases CINAHL ${ }^{\circledR}$, PsychINFO $^{\circledR}$, EMBase $^{\mathrm{TM}}$, and MEDLINE ${ }^{\circledR}$ through Ovid ${ }^{\circledR}$ were searched in March 2019.

\section{Selecting Studies}

A total of 476 articles were retrieved from an electronic search, and 1 article was found from a manual search. Seventyseven articles were removed as duplicates, and 370 articles were excluded for having nonrelevant titles and abstracts (Figure 1). The articles focused on other general nursing degree programs, program development, or program tests within short periods. The full text of the 30 remaining studies was independently reviewed by two authors for its relation to the specific research 
topics, and an additional 12 articles were excluded because they focused on an associate degree in nursing, socialization, learning style, different populations, faculty experience, pilot programs, and students' interest in nursing. Finally, 15 studies were included in the analysis.

\section{Compiling the Data}

A data extraction form was developed to record information regarding author(s), year, country, study purpose and design, subjects, and program outcomes for each study. The primary reviewer collected and recorded study data on extraction forms, and the secondary reviewer validated the final data forms.

\section{Summarizing the \\ Data and Reporting \\ the Results}

The findings of this review are described and discussed in relation to the four levels of the Kirkpatrick model: 1) reaction, 2) learning, 3) behavior, and 4) results. After review of each article, outcomes on each

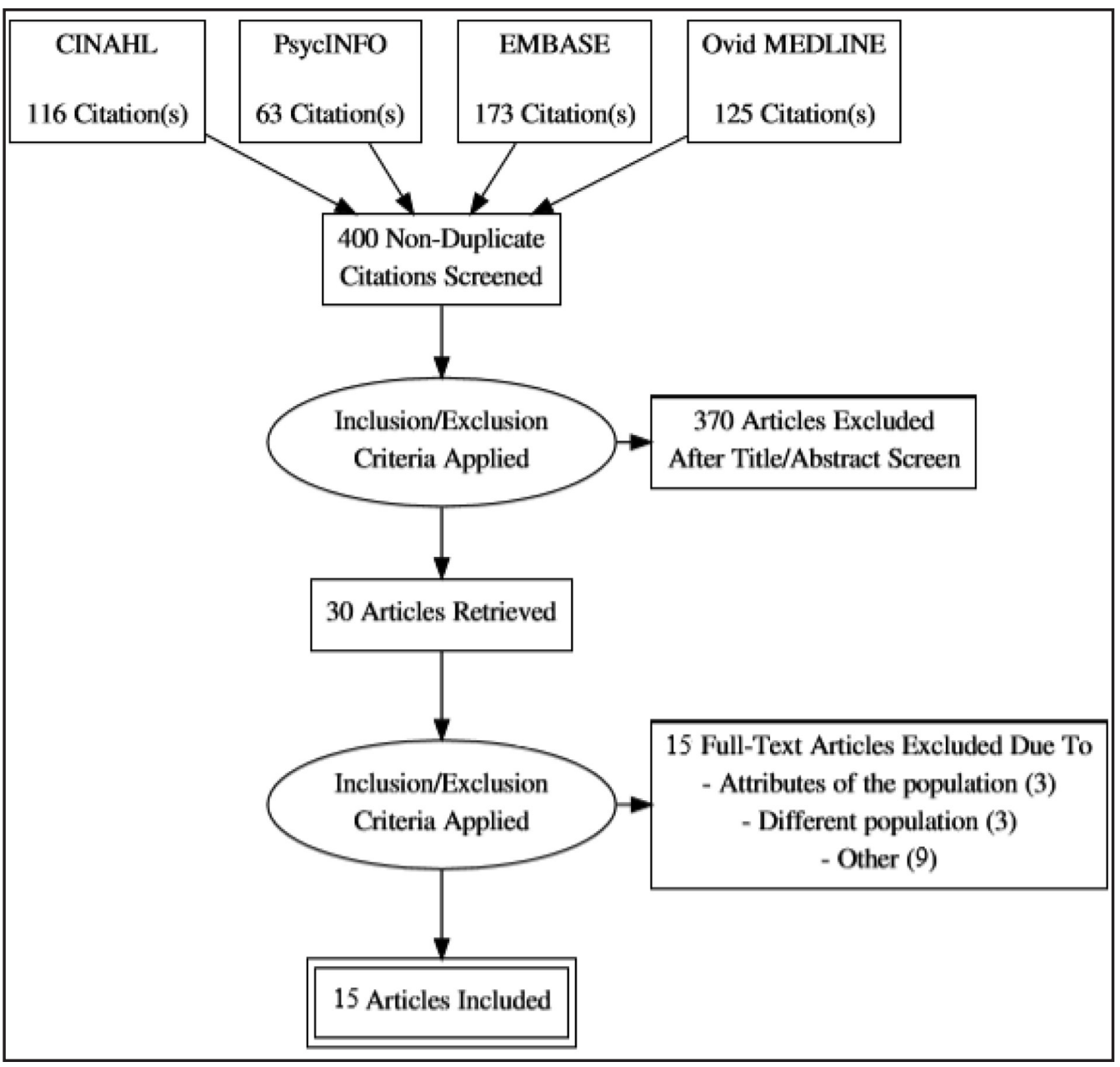

Figure 1. Study selection process flowchart.

level were recorded: student/ graduate program satisfaction and attrition or completion rate for Level 1; grade point average (GPA), NCLEX-RN pass rate, and clinical preparedness for Level 2; professional development and nursing career satisfaction for Level 3; and graduates' safe and quality patient care in practice and workforce retention for Level 4. Details of the 15 studies are provided in Tables A-B; available in the online version of this article.

\section{RESULTS}

\section{Study Characteristics}

Of the 15 articles reviewed, 10 reported outcomes of ABSN programs in the United States, and 5 reported outcomes of AMSN programs in the United States, Australia, and Canada (Tables A-B). Eight studies used a descriptive design, whereas seven studies used a comparative method to compare ABSN programs with traditional nursing programs (Aktan et al., 2009; Kaddoura et al., 2017; McDonald, 1995; Moe et al., 2009; Payne et al., 2014; Roberts et al., 2001; Schwartz et al., 2015). In general, program students or graduates in individual programs or hospitals were recruited as study participants in in-

dividual programs or hospitals; one study included nurse managers as well as program graduates recruited in three hospitals (Ziehm et al., 2011).

\section{ABSN and AMSN Program Outcomes}

Two of the 15 studies evaluated the program completion rates of students. Among ABSN and AMSN students, 91.9\% and $80 \%$ completed their programs, respectively (Carty et al., 2007; Johnson \& Johnson, 2008). Regarding attrition rates, one ABSN program and four cohorts of AMSN students had attrition rates of $14 \%$ (Penprase \& Harris, 2013) and $0 \%$ to $3.6 \%$, respectively (Ziehm et al., 2011). Two studies reported graduates' overall program satisfaction. In a study by Kemsley et al. (2011), 86\% of ABSN graduates reported that their program met their expectations and that they would recommend it to others. Shatto et al. (2016) also found that all AMSN graduates were satisfied with their program upon graduation.

The most commonly used program outcomes included academic achievements such as GPA, NCLEX-RN pass rates, and employment after graduation. Only one study (Shatto et al., 2016) did not use any of these outcomes; it instead used prepa- 
ration for a nursing career at graduation. Six studies reported the cumulative GPA of students or graduates on a 4-point scale (Cantlay et al., 2017; Carty et al., 2007; Kaddoura et al., 2017; Moe et al., 2009; Payne et al., 2014; Schwartz et al., 2015), and students or graduates of both ABSN and AMSN programs showed good academic performance (GPA $\geq 3.0)$. Eleven studies reported the NCLEX-RN pass rates of graduates on their first attempt, with the pass rate of ABSN graduates ranging from $85.7 \%$ to $100 \%$ in nine studies (Aktan et al., 2009; Bentley, 2006; Kaddoura et al., 2017; Kemsley et al., 2011; McDonald, 1995; Moe et al., 2009; Payne et al., 2014; Penprase \& Harris, 2013; Schwartz et al., 2015). Similarly, the pass rates of AMSN graduates in two studies were $87.5 \%$ and $94 \%$ (Johnson \& Johnson, 2008; Ziehm et al., 2011). Finally, examination scores measured by Health Education Systems Inc. were reported for ABSN program students or graduates in three studies (Kaddoura et al., 2017; Moe et al., 2009; Payne et al., 2014), and as expected, these participants consistently performed better than their traditional BSN counterparts in other studies.

Four studies reported employment status of graduates after program completion. For ABSN graduates, the employment rate was reported as $87.2 \%$ in one study (Schwartz, 2015), and another study (Kemsley, 2011) reported a job placement rate of $98.4 \%$ within 8 to 24 months after graduation. Similarly, for AMSN graduates, a job placement rate of $98 \%$ within the same time period was reported by both Ezer et al. (1991) and Cantlay et al. (2017).

Three ABSN studies and four AMSN studies assessed the clinical competency or preparedness for clinical roles using a self-report approach. In one ABSN study, $82 \%$ of graduate respondents reported they felt prepared to begin practice in clinical settings (Kemsley et al., 2011), whereas $30 \%$ of graduates in another ABSN study reported feeling unprepared to roletransition (Aktan et al., 2009). McDonald (1995) measured the objective nursing performance of ABSN students with the six-D scale and reported that the ABSN students achieved a higher average score than the TBSN students. In the four AMSN studies, $78 \%$ of graduates surveyed reported being prepared to meet the demands of the current position (Ezer et al., 1991), and $71 \%$ felt themselves to be sufficiently prepared as a beginning practitioner in a general nursing setting (Cantlay et al., 2017). Shatto et al. (2016) assessed the nursing career preparation of AMSN graduates at four time points after graduation until 1 year after graduation. Reported perceptions of nursing career preparation varied over time, with $100 \%$ of graduates reporting such preparation at graduation, $88.2 \%$ at 6 months, and again $100 \%$ at 1 year. Ziehm et al. (2011) examined AMSN graduates' performance in clinical practice using both the graduates' and their nurse managers' performance assessments. Nurse managers perceived that AMSN graduates performed better than the graduates thought they had.

Five studies reported professional development related outcomes. ABSN graduates pursuing or enrolled in advanced nursing programs ranged from $18.8 \%$ to $43 \%$ in four ABSN studies (Aktan et al., 2009; Carty et al., 2007; Kemsley et al., 2011; Schwartz et al., 2015). Professional certificates were reported for $48 \%$ in one study (Aktan, 2009) and for 27\% of ABSN graduates in another study (Schwartz et al., 2015). Only one AMSN study reported professional development; $40 \%$ of graduates surveyed had professional membership and $27 \%$ engaged in research (Ezer et al., 1991).

Five studies reported the overall nursing career satisfaction of graduates. ABSN graduates had a high degree of satisfaction with their nursing career, with a 90.7 average score on the Mariani Nursing Career Satisfaction Scale (Schwartz et al., 2015), and $86 \%$ of ABSN graduates stated that the nursing profession met their expectations (Kemsley et al., 2011). More than $86 \%$ of AMSN graduates expressed satisfaction with their nursing career in studies by Cantlay et al. (2017) and Ezer et al. (1991), and career satisfaction was reported by $93.4 \%$ of AMSN graduates 1 year after graduation in a study by Shatto et al. (2016).

Of the 15 studies reviewed, only ABSN studies compared their participants with their traditional counterparts in terms of educational outcomes. ABSN students and graduates showed academic outcomes (GPAs or exit examination scores) that were either better than (Kaddoura et al., 2017; McDonald, 1995; Moe et al., 2009) or similar to (Aktan et al., 2009; Payne et al., 2014) those of TBSN groups. All ABSN studies that reported NCLEX-RN pass rates were equal to or higher than TBSN groups (Aktan et al., 2009; Bentley, 2006; Kaddoura et al., 2017; McDonald, 1995; Moe et al., 2009; Payne et al., 2014; Schwartz et al., 2015). ABSN students also reported significantly better preparation for clinical practice compared with their TBSN counterparts (Aktan et al., 2009; McDonald, 1995), but no significant differences in employment rates were found between ABSN and TBSN graduates (Aktan et al., 2009). Professional outcomes were measured in terms of professional memberships and certifications, and these outcomes did not differ significantly between ABSN and TBSN graduates (Aktan et al., 2009). However, TBSN graduates showed higher intention to earn an advanced nursing degree (Schwartz et al., 2015).

\section{Outcomes According to the Four Levels of the Kirkpatrick Model}

To answer the second research question, the outcomes presented in each study were categorized according to the four levels of the Kirkpatrick model (Tables A-B). Outcome criteria associated with each level were determined based on the definition of each level provided by the Kirkpatrick model and relevant literature. Level 1 (reaction) was evaluated in terms of learners' satisfaction with a program, and Level 2 (learning) involved assessment of the knowledge and skill acquisition of learners. Level 3 (behavior) indicated how much the knowledge and skills obtained in the program were applied in on-the-job performance, and Level 4 (results) involved determination of program benefits to health care facilities. In the health care system, Level 4 can be assessed in terms of benefits to patients or practice, such as patient safety or quality of care (Johnston et al., 2018). Such benefits can be considered the ultimate goals of accelerated second-degree nursing programs but are difficult to measure. The results obtained from application of the Kirkpatrick model are discussed below.

Level 1: Reaction. Reaction is the easiest outcome to measure and is often directly evaluated in terms of students' program satisfaction and indirectly assessed in terms of program completion and attrition rates. Of 15 studies, six (40\%) mea- 
sured the first level of the Kirkpatrick model. One ABSN study asked students whether they would recommend the program to others in a self-report assessment (Kemsley et al., 2011), and one AMSN study assessed overall student satisfaction with the program (Shatto et al., 2016). In addition, four studies evaluated program completion or attrition rates, which can be considered to represent students' reaction to the program.

Level 2: Learning. Level 2 involved evaluation of program outcomes, including acquisition of knowledge and skills. A wide range of academic achievement generally was observed. In total, $11(73 \%)$ of 15 studies evaluated NCLEX-RN pass rates, and six $(40 \%)$ evaluated cumulative GPAs and exit examination scores. Six (40\%) studies assessed the clinical preparedness of ABSN/AMSN program students and graduates using either a self-report approach or an objective measure. Four (26.7\%) studies also evaluated employment after program completion.

Level 3: Behavior. According to the Kirkpatrick model, Level 3 evaluation is related to the degree of change in students' behavior outside the learning environment and often is measured by observation. In the context of nursing education and the nursing profession, this would refer to behavioral change in the clinical setting. Level 3 in this review included professional activity during clinical practice, such as pursuing an advanced nursing degree, serving on professional committees, earning professional certificates, and clinical role performance, as well as nursing career satisfaction. Overall, $5(33 \%)$ studies reported professional activities of their graduates after program completion, and 5 studies assessed nursing career satisfaction of ABSN or AMSN graduates. One study asked nurse managers to objectively evaluate RN performance of AMSN graduates, resulting in AMSN graduates being rated very effective in their RN roles (Ziehm et al., 2011).

Level 4: Results. Results in Level 4 of the Kirkpatrick model refer to the degree to which targeted outcomes and changes in practice occurred due to program completion. No studies included in this review assessed the beneficial effects of ABSN or AMSN programs on either patient outcomes or clinical practice, or their ultimate impact on health care facilities.

\section{DISCUSSION}

In response to the global nursing shortage, the need to effectively educate nurses in a fast-tracked and upgraded manner has increased in nursing academia. Currently, ABSN and AMSN programs for non-nurses with a baccalaureate degree are available in several countries, including the United States. These programs may be attractive to international nursing educators who are looking for an innovative nursing education model to produce high-quality, well-prepared nurses to perform advanced roles. This scoping review evaluated and compared the effectiveness of ABSN and AMSN programs using the Kirkpatrick model. Of the 15 studies reviewed, 13 were conducted in the United States, one in Australia, and one in Canada. Although ABSN and AMSN programs have been implemented extensively in the United States, further research on such programs is needed in other countries where accelerated seconddegree nursing programs are being implemented. In addition, except for one study conducted in three hospitals (Ziehm et al.,
2011), the individual studies were conducted in a single nursing school or health care facility. The study results obtained are valuable, but differing program outcome indicators made it difficult to meaningfully compare the effectiveness of accelerated second-degree programs.

This study is the first to apply the Kirkpatrick evaluation model to accelerated second-degree nursing programs. As for the first level, four studies assessed the perception of students and graduates of ABSN or AMSN programs. Overall satisfaction with ABSN and AMSN programs was high in students and graduates, primarily because they obtained a degree quickly (Johnson \& Johnson, 2008; Kemsley et al., 2011), and program flexibility also was valued (Roberts et al., 2001). Attrition rates of ABSN and AMSN students were lower than those observed in traditional nursing programs (Penprase \& Harris, 2013; Ziehm et al., 2011). Nevertheless, several strategies for increasing rates of ABSN and AMSN program completion were suggested in the studies reviewed, including revising the curriculum, providing a more in-depth orientation, and developing meaningful relationships with faculty and peers (Moe et al., 2009). For example, admission interviews and orientations that make students aware of financial issues and the time commitment required for program success likely would reduce program attrition (Johnson \& Johnson, 2008). In addition, a conscious decision to choose an accelerated program over one's current career suggests a wish to explore the new possibilities offered by a second career (McDonald, 1995).

Level 2 in the Kirkpatrick model evaluates learners' knowledge and skill acquisition from education programs. All 15 studies reported academic achievements that allowed evaluation on this level. The ABSN students and graduates consistently showed a better or at least similar performance in terms of GPA, exit examination scores, and NCLEX-RN pass rates compared with their traditional counterparts, and AMSN graduates showed similar outcomes. The academic success of second-degree students may have been related to high admission criteria, such as a GPA of 3.0 or 4.0 (Carty et al., 2007), and thus to students' previous successful academic performance. Moreover, the adult learners in second-degree programs tend to be mature and strongly motivated to pursue professional nursing careers (Korvick et al., 2008).

In terms of clinical preparedness, $30 \%$ of ABSN and AMSN graduates reported they had difficult role transitions or were not prepared for clinical roles (Aktan et al., 2009; Cantlay et al., 2017). AMSN graduates rate themselves lower than did nurse managers early in their careers by evaluating employment performance criteria (Ziehm et al., 2011). In general, due to the accelerated nature of these programs, students seemed to lack sufficient time to learn clinical skills, causing them to feel less confident. Emphasizing the transition from student to nurse, including mentorship to help graduates transition, and meeting evolving unit needs were identified to improve the ABSN program (Kemsley et al., 2011). AMSN graduates' lower self-ratings and lack of self-confidence may be attributable to the high expectations for master's degree-prepared nurses; such graduates may experience imposter syndrome because they were educated to become clinical nurse leaders and nurse educators within a relatively short period of time (Ziehm et al., 2011). 
As building competence leads to comfort (Sherman, 2013), the AMSN program could facilitate clinical learning in second-degree students by providing more opportunities for clinical skill practice in a safe environment or by using simulations (Kemsley et al., 2011).

In ABSN and AMSN graduates, NCLEX-RN pass rates and employment rates were higher for RNs than the national average rates in the corresponding year, which is positive for producing licensed nurses in a shorter time frame (Aktan et al., 2009; Kemsley et al., 2011). Because the ratios of BSN and MSN degree holders among the RNs employed in a hospital are essential criteria for Magnet recognition and accreditation, those program graduates might have been equally welcomed. However, given the high turnover rates of new graduate nurses, future studies are needed to obtain solid evidence regarding the programs' efficacy in terms of long-term employment. In addition, male students applying for second-degree programs seemed to perceive job opportunities and career stability as particularly important (Everett et al., 2013). Furthermore, seconddegree nursing programs' recruitment of more male students and consequent promotion of gender balance in the nursing profession constitute one of the advantages of such programs (Harding et al., 2018).

Next, Level 3 evaluates behavioral change of students after nursing program graduation. ABSN graduates had a lower intention to acquire an advanced nursing degree compared with TBSN graduates (Schwartz et al., 2015). This finding may be attributable to the fact that on average, ABSN students were older, had family responsibilities, and had less time available for paid jobs, all of which negatively impacted their motivation to pursue a higher degree (Kemsley et al., 2011). Despite these challenges, both ABSN and AMSN program graduates showed high satisfaction with their overall nursing careers. Given the known importance of networking relationships to career satisfaction (Schwartz et al., 2015), it can be assumed that the older graduates of these programs had mature social skills that facilitated networking.

Surprisingly, none of the studies could be evaluated on Level 4, which involves patient outcomes. Good patient outcomes may be the most important long-term goal of accelerated nursing programs. We cannot assume that graduates will automatically perform successfully in clinical settings due to their good school performance. More study is warranted to investigate the direct or indirect effect of second-degree programs on patient outcomes such as morbidity, mortality, and health care cost. Overall, consultations among nursing education stakeholders regarding the findings of this study are warranted to obtain their insights, as such consultation is an optional component of the scoping study.

\section{CONCLUSION}

This scoping review supports that both ABSN and AMSN programs are a successful and innovative approach to preparing qualified licensed nurses in a short time period. Students and graduates of both programs were satisfied with program curricula and characteristics; however, the fast-moving curricula of accelerated programs presented an ongoing area of concern re- garding clinical preparedness. Therefore, accelerated programs need to develop better strategies to improve clinical competency and student confidence, as well as to ease the transition to the work environment. Although the lower levels of the Kirkpatrick model were assessed extensively in the reviewed studies, future researchers should investigate the degree to which accelerated second-degree programs improve their graduates' clinical practice and enhance patient outcomes. In addition, these programs' ultimate contributions to health care facilities and to meeting the demand for a well-trained nursing workforce merit further investigation.

\section{REFERENCES}

Aktan, N. M., Bareford, C. G., Bliss, J. B., Connolly, K., DeYoung, S., Lancellotti Sullivan, K., \& Tracy, J. (2009). Comparison of outcomes in a traditional versus accelerated nursing curriculum. International Journal of Nursing Education Scholarship, 6(1), Article 13. https://doi. org/10.2202/1548-923X.1639

American Association of Colleges of Nursing. (2019). Accelerated baccalaureate and master's degrees in nursing. https://www. aacnnursing.org/Nursing-Education-Programs/Accelerated-Programs

Arksey, H., \& O'Malley, L. (2005). Scoping studies: Towards a methodological framework. International Journal of Social Research Methodology, 8(1), 19-32. https://doi.org/10.1080/1364557032000119616

Bentley, R. (2006). Comparison of traditional and accelerated baccalaureate nursing graduates. Nurse Educator, 31(2), 79-83. https://doi org/10.1097/00006223-200603000-00010 PMID:16601615

Cantlay, A., Salamanca, J., Golaw, C., Wolf, D., Maas, C., \& Nicholson, P. (2017). Self-perception of readiness for clinical practice: A survey of accelerated masters program graduate registered nurses. Nurse Education in Practice, 24, 34-42. https://doi.org/10.1016/j.nepr.2017.03.005 PMID:28355578

Carty, R. M., Moss, M. M., Al-Ayer, W., Kowitlawakul, Y., \& Arietti, L. (2007). Predictors of success for Saudi Arabian students enrolled in an accelerated baccalaureate degree program in nursing in the United States. Journal of Professional Nursing, 23(5), 301-308. https://doi. org/10.1016/j.profnurs.2007.06.001 PMID:17903789

Ding, D., Lawson, K. D., Kolbe-Alexander, T. L., Finkelstein, E. A. Katzmarzyk, P. T., van Mechelen, W., Pratt, M., \& the Lancet Physical Activity Series 2 Executive Committee. (2016). The economic burden of physical inactivity: A global analysis of major non-communicable diseases. Lancet, 388(10051), 1311-1324. https://doi.org/10.1016/ S0140-6736(16)30383-X PMID:27475266

Dorri, S., Akbari, M., \& Dorri Sedeh, M. (2016). Kirkpatrick evaluation model for in-service training on cardiopulmonary resuscitation. Iranian Journal of Nursing and Midwifery Research, 21(5), 493-497. https:// doi.org/10.4103/1735-9066.193396 PMID:27904633

Everett, B., Salamonson, Y., Trajkovski, S., \& Fernandez, R. (2013). Demographic and academic-related differences between standard-entry and graduate-entry nursing students: A prospective correlational survey. Nurse Education Today, 33(7), 709-713. https://doi.org/10.1016/j. nedt.2013.03.006 PMID:23582430

Ezer, H., MacDonald, J., \& Gros, C. P. (1991). Follow-up of generic master's graduates: Viability of a model of nursing in practice. Canadian Journal of Nursing Research, 23(3), 9-20. PMID:1802380

Harding, T., Jamieson, I., Withington, J., Hudson, D., \& Dixon, A. (2018). Attracting men to nursing: Is graduate entry an answer? Nurse Education in Practice, 28, 257-263. https://doi.org/10.1016/j.nepr.2017.07.003 PMID:28739357

Heydari, M. R., Taghva, F., Amini, M., \& Delavari, S. (2019). Using Kirkpatrick's model to measure the effect of a new teaching and learning methods workshop for health care staff. BMC Research Notes, 12(1), 388. https://doi.org/10.1186/s13104-019-4421-y PMID:31292006

Isyanto, A. Y., Suprajogo, T., Roshonah, A. F., \& Sari, D. A. (2020). Impact of CSO manage training programs on individual and organizational performance. European Journal of Business and Management, 12(2), 35-39. https://doi.org/10.7176/EJBM/12-2-05 
Jackson, M., \& Marchi, N. (2020). Graduate-entry education for nonnurses: Preparation, pathways, and progress. Nursing Education Perspectives, 41(1), 30-32. https://doi.org/10.1097/01.NEP.0000000000000510 PMID:31860482

Jan, S., Laba, T. L., Essue, B. M., Gheorghe, A., Muhunthan, J., Engelgau, M., Mahal, A., Griffiths, U., McIntyre, D., Meng, Q., Nugent, R., \& Atun, R. (2018). Action to address the household economic burden of non-communicable diseases. Lancet, 391(10134), 2047-2058. https:// doi.org/10.1016/S0140-6736(18)30323-4 PMID:29627161

Johnson, S. A., \& Johnson, L. J. (2008). Second-degree, entry-into-practice master's of nursing program: Lessons learned. Nurse Educator, 33(5), 228-232. https://doi.org/10.1097/01.NNE.0000312217.67461.39 PMID: 18769329

Johnston, S., Coyer, F. M., \& Nash, R. (2018). Kirkpatrick's evaluation of simulation and debriefing in health care education: A systematic review. Journal of Nursing Education, 57(7), 393-398. https://doi. org/10.3928/01484834-20180618-03 PMID:29958308

Jones, C., Randall, S., \& Fraser, J. (2020). Evaluation of nurse training using Kirkpatrick's model: A mixed-methods approach. SAGE Research Methods Cases. https://doi.org/10.4135/9781529709681

Kaddoura, M. A., Flint, E. P., Van Dyke, O., Yang, Q., \& Chiang, L. C. (2017). Academic and demographic predictors of NCLEX-RN pass rates in first- and second-degree accelerated BSN programs. Journal of Professional Nursing, 33(3), 229-240. https://doi.org/10.1016/j. profnurs.2016.09.005 PMID:28577816

Kemsley, M., McCausland, L., Feigenbaum, J., \& Riegle, E. (2011). Analysis of graduates' perceptions of an accelerated bachelor of science program in nursing. Journal of Professional Nursing, 27(1), 50-58. https:// doi.org/10.1016/j.profnurs.2010.09.006 PMID:21272836

Kirkpatrick, J. D., \& Kirkpatrick, W. K. (2016). Kirkpatrick's four levels of training evaluation. ATD Press.

Korvick, L. M., Wisener, L. K., Loftis, L. A., \& Williamson, M. L. (2008). Comparing the academic performance of students in traditional and second-degree baccalaureate programs. Journal of Nursing Education, 47(3), 139-141. https://doi.org/10.3928/01484834-20080301-10 PMID: 18380269

Mark, H. D., Twigg, R. D., Barber, L., \& Warren, N. (2019). Entry-level master's programs in nursing: Review of programmatic features. Journal of Nursing Education, 58(9), 525-529. https://doi.org/10.3928/ 01484834-20190819-05 PMID:31461520

McDonald, W. K. (1995). Comparison of performance of students in an accelerated baccalaureate nursing program for college graduates and a traditional nursing program. Journal of Nursing Education, 34(3), 123-127. PMID:7745475

Ministry of Health and Welfare. (2018). The policy to help improve nurse work environment and treatment. http://www.mohw.go.kr/react/al/ sal0301vw.jsp?PAR_MENU_ID=04\&MENU_ID=0403\&CONT_ $\mathrm{SEQ}=344262$ \&page $=1$

Moe, K., Brockopp, D. A., Walmsley, L. A., Davis, J., Butler, K., Diebold, C., \& Maiti, S. R. (2009). A pilot project to evaluate the academic performance, abilities, and satisfaction of second-degree students. Nursing Education Perspectives, 30(4), 226-228. PMID:19753855

Organisation for Economic Cooperation and Development. (2017). Health at a glance 2017: OECD indicators. https://www.oecd-ilibrary.org/ content/publication/health_glance-2017-en

Payne, L. K., Glaspie, T., \& Rosser, C. (2014). Comparison of select outcomes between traditional and accelerated BSN programs: A pilot study. Nursing Education Perspectives, 35(5), 332-334. https://doi. org/10.5480/12-988.1 PMID:25291931

Payne, L. K., \& Mullen, P. (2014). Outcome measures for traditional and accelerated nursing graduates: An integrative literature review. Nursing Education Perspectives, 35(4), 238-243. https://doi. org/10.5480/12-1008.1 PMID:25158418

Penprase, B. B., \& Harris, M. A. (2013). Accelerated second-degree nursing students: Predictors of graduation and NCLEX-RN first-time pass rates. Nurse Educator, 38(1), 26-29. https://doi.org/10.1097/ NNE.0b013e318276df16 PMID:23222629

Rafferty, M., \& Lindell, D. (2011). How nurse managers rate the clinical competencies of accelerated (second-degree) nursing graduates. Journal of Nursing Education, 50(6), 355-358. https://doi. org/10.3928/01484834-20110228-07 PMID:21366163

Roberts, K., Mason, J., \& Wood, P. (2001). A comparison of a traditional and an accelerated basic nursing education program. Contemporary Nurse, 11(2-3), 283-287. https://doi.org/10.5172/conu.11.2-3.283 PMID: 11924627

Schwartz, J., Sharts-Hopko, N. C., \& Bhattacharya, A. (2015). Comparison of demographics, professional outcomes, and career satisfaction in accelerated and traditional baccalaureate nursing graduates. Journal of Nursing Education, 54(3, Suppl), S39-S46. https://doi. org/10.3928/01484834-20150218-11 PMID:25693112

Shatto, B., Meyer, G., \& Delicath, T. A. (2016). The transition to practice of direct entry clinical nurse leader graduates. Nurse Education in Practice, 19, 97-103. https://doi.org/10.1016/j.nepr.2016.05.008 PMID:27428700

Sherman, R. O. (2013). Imposter syndrome: When you feel like you're faking it. American Nurse Today, 8(5), 57-58.

Ziehm, S. R., Uibel, I. C., Fontaine, D. K., \& Scherzer, T. (2011). Success indicators for an accelerated masters entry nursing program: Staff RN performance. Journal of Nursing Education, 50(7), 395-403. https:// doi.org/10.3928/01484834-20110429-02 PMID:21534500 
Table A

Description of ABSN Studies and Results Included $(n=10)$

\begin{tabular}{|c|c|c|c|c|c|c|c|}
\hline \multirow{2}{*}{$\begin{array}{l}\text { Author (year), } \\
\text { country }\end{array}$} & \multirow[t]{2}{*}{ Study purpose } & \multirow[t]{2}{*}{ Study design } & \multirow{2}{*}{$\begin{array}{l}\text { Subjects } \\
(N)\end{array}$} & \multicolumn{4}{|c|}{ Key findings by Kirkpatrick levels } \\
\hline & & & & Level 1 & Level 2 & Level 3 & Level $4^{\mathrm{a}}$ \\
\hline $\begin{array}{l}\text { Carty et al. } \\
\text { (2007), United } \\
\text { States }\end{array}$ & $\begin{array}{l}\text { To define predictors of } \\
\text { success for Saudi Arabian } \\
\text { students in a U.S. ABSN } \\
\text { program }\end{array}$ & $\begin{array}{l}\text { Descriptive } \\
\text { study }\end{array}$ & $\begin{array}{l}\text { ABSN } \\
\text { graduates } \\
(N=37)\end{array}$ & $\begin{array}{l}\text { Completion: } \\
91.9 \%\end{array}$ & $\begin{array}{l}\text { GPA: } 3.46 \\
\text { (Male), } 3.29 \\
\text { (Female) }\end{array}$ & $\begin{array}{l}\text { Advanced nursing } \\
\text { degree: } 43 \%\end{array}$ & \\
\hline $\begin{array}{l}\text { Aktan et al. } \\
\text { (2009), United } \\
\text { States }\end{array}$ & $\begin{array}{l}\text { To determine the } \\
\text { effectiveness of ABSN } \\
\text { program }\end{array}$ & $\begin{array}{l}\text { Comparison } \\
\text { study }\end{array}$ & $\begin{array}{l}\text { ABSN } \\
\text { graduates } \\
(N=40), \\
\text { TBSN } \\
\text { graduates } \\
(N=33)\end{array}$ & & $\begin{aligned} & \cdot \text { NCLEX-RN } \\
& \text { pass: } 92.5 \% \\
&(84.8 \%) \\
& \cdot \text { Role transition } \\
& \text { difficulty: } 30.0 \% \\
&(27.3 \%)\end{aligned}$ & $\begin{array}{l}\text { Professional } \\
\text { certificate: } 48 \% \\
(63.6 \%) \\
\text { - Committee } \\
\text { service: } 53 \% \\
(48.5 \%)\end{array}$ & \\
\hline $\begin{array}{l}\text { Kaddoura et al. } \\
\text { (2017), United } \\
\text { States }\end{array}$ & $\begin{array}{l}\text { To compare predictors of } \\
\text { NCLEX-RN pass rates in } \\
\text { ABSN and TBSN programs }\end{array}$ & $\begin{array}{l}\text { Comparison } \\
\text { study }\end{array}$ & $\begin{array}{l}\text { ABSN } \\
\text { graduates } \\
(N=173), \\
\text { TBSN } \\
\text { graduates } \\
(N=62)\end{array}$ & & $\begin{array}{l}\text { GPA: } 3.26(3.00) \\
\text { - HESI exit } \\
\text { examination } \\
\text { scores: } 838(767) \\
\text {. NCLEX-RN } \\
\text { pass: } 88.4 \% \\
(71.0 \%)\end{array}$ & & \\
\hline $\begin{array}{l}\text { Kemsley et al. } \\
(2011), \text { United } \\
\text { States }\end{array}$ & $\begin{array}{l}\text { To analyze the perceptions } \\
\text { of ABSN graduates }\end{array}$ & $\begin{array}{l}\text { Mixed- } \\
\text { method } \\
\text { study }\end{array}$ & $\begin{array}{l}\text { ABSN } \\
\text { graduates } \\
(N=28)\end{array}$ & $\begin{array}{l}\text { Recommendation } \\
\text { to other: } 86 \%\end{array}$ & $\begin{array}{l}\text { - NCLEX-RN pass: } \\
85.7 \% \\
\text { - Employment: } \\
98.4 \% \\
\text { - Practice } \\
\text { preparation: } 82 \%\end{array}$ & $\begin{array}{l}\text { Advanced nursing } \\
\text { degree: } 28.6 \% \\
\text { Profession met } \\
\text { expectation: } 86 \%\end{array}$ & \\
\hline $\begin{array}{l}\text { McDonald } \\
\text { (1995), United } \\
\text { States }\end{array}$ & $\begin{array}{l}\text { To compare the academic } \\
\text { achievement and nursing } \\
\text { performance between } \\
\text { ABSN and TBSN students }\end{array}$ & $\begin{array}{l}\text { Quasi- } \\
\text { experimental } \\
\text { study }\end{array}$ & $\begin{array}{l}\text { ABSN } \\
\text { students } \\
(N=27) \\
\text { TBSN } \\
\text { students } \\
(N=29)\end{array}$ & & $\begin{array}{l}\text { NCLEX-RN pass: } \\
90 \%(70 \%) \\
\text { Nursing } \\
\text { performance by } \\
\text { six-D scale: } 146 \\
(141)\end{array}$ & & \\
\hline $\begin{array}{l}\text { Moe et al. } \\
\text { (2009), United } \\
\text { States }\end{array}$ & $\begin{array}{l}\text { To compare the } \\
\text { performance and } \\
\text { satisfaction between ABSN } \\
\text { and TBSN students }\end{array}$ & $\begin{array}{l}\text { Comparison } \\
\text { study }\end{array}$ & $\begin{array}{l}\text { ABSN } \\
\text { students } \\
(N=35), \\
\text { TBSN } \\
\text { students } \\
(N=115)\end{array}$ & & $\begin{array}{l}\text { GPA: } 3.19(3.33) \\
\text { HESI Exit } \\
\text { examination } \\
\text { scores: } 900.5 \\
(896.7)\end{array}$ & & \\
\hline
\end{tabular}




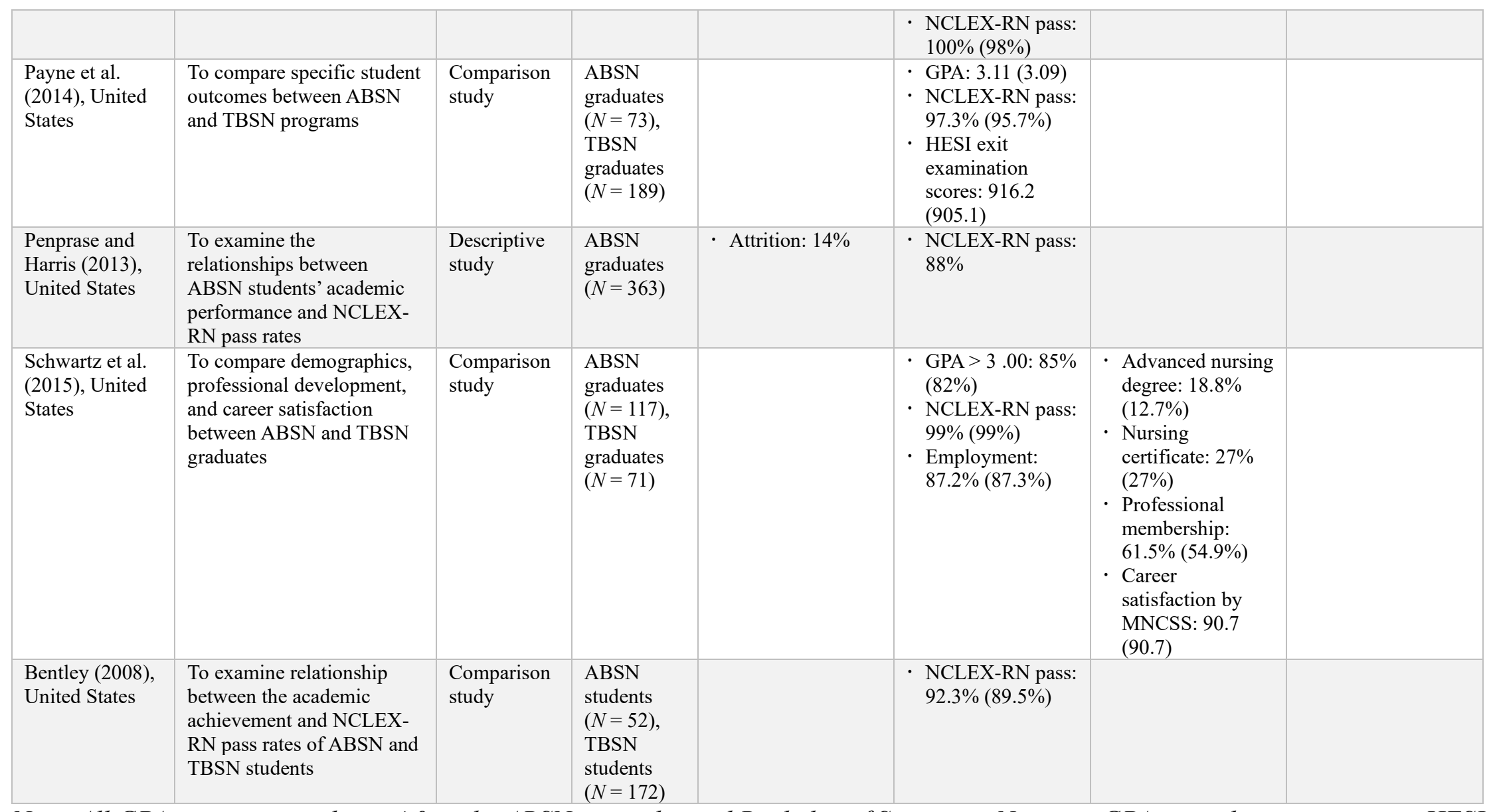

Note. All GPAs are converted to a 4.0 scale. ABSN = accelerated Bachelor of Science in Nursing; GPA = grade point average; HESI = Health Education Systems, Inc.; MNCSS: Mariani Nursing Career Satisfaction Scale; NCLEX-RN = National Council Licensing Examination for Registered Nurses; TBSN = traditional Bachelor of Science in Nursing.

${ }^{a}$ No data for Level 4.

${ }^{b}$ Completed within 3 years. 
Table B

Description of AMSN Studies and Results Included $(n=5)$

\begin{tabular}{|c|c|c|c|c|c|c|c|}
\hline \multirow{2}{*}{$\begin{array}{l}\text { Author (year), } \\
\text { country }\end{array}$} & \multirow{2}{*}{ Study purpose } & \multirow[t]{2}{*}{ Study design } & \multirow[t]{2}{*}{ Subjects $(N)$} & \multicolumn{4}{|c|}{ Key findings by Kirkpatrick levels } \\
\hline & & & & Level 1 & Level 2 & Level 3 & Level 4 \\
\hline $\begin{array}{l}\text { Ezer et al. } \\
\text { (1991), United } \\
\text { States }\end{array}$ & $\begin{array}{l}\text { To track AMSN } \\
\text { graduates' career } \\
\text { paths in nursing } \\
\text { following } \\
\text { program } \\
\text { completion }\end{array}$ & $\begin{array}{l}\text { Descriptive } \\
\text { study }\end{array}$ & $\begin{array}{l}\text { AMSN } \\
\text { graduates } \\
(n=48)\end{array}$ & & $\begin{array}{l}\text { Employment: } \\
98 \% \\
\text { - Preparation for } \\
\text { the current } \\
\text { position: } 78 \%\end{array}$ & $\begin{array}{l}\text { Professional } \\
\text { membership: } \\
40 \% \\
\text { - Engaged in } \\
\text { research: } 27 \% \\
\text { - Nursing career } \\
\text { satisfaction: } \\
87 \%\end{array}$ & \\
\hline $\begin{array}{l}\text { Johnson \& } \\
\text { Johnson (2008), } \\
\text { United States }\end{array}$ & $\begin{array}{l}\text { To examine } \\
\text { impact of the } \\
\text { AMSN program } \\
\text { on graduates' } \\
\text { professional } \\
\text { nursing practice }\end{array}$ & $\begin{array}{l}\text { Descriptive } \\
\text { study } \\
\text { ( } 3 \text { cohorts) }\end{array}$ & $\begin{array}{l}\text { AMSN } \\
\text { graduates } \\
(n=64)\end{array}$ & $\begin{array}{l}\text { Completion: } \\
80 \%\end{array}$ & $\begin{array}{l}\text { - } \text { NCLEX-RN }^{\circledR} \\
\text { pass: } 87.5 \%\end{array}$ & & \\
\hline $\begin{array}{l}\text { Ziehm et al. } \\
\text { (2011), United } \\
\text { States }\end{array}$ & $\begin{array}{l}\text { To evaluate the } \\
\text { employment } \\
\text { performance of } \\
\text { AMSN graduates }\end{array}$ & $\begin{array}{l}\text { Descriptive } \\
\text { study, focus } \\
\text { group } \\
\text { interview }\end{array}$ & $\begin{array}{l}\text { AMSN } \\
\text { graduates in } \\
\text { three hospital } \\
\text { ( } 16 \text { cohorts }), \\
(n=37) \\
\text { Nurse managers } \\
(n=15)\end{array}$ & $\begin{array}{l}\text { - Attrition: } 0 \% \text { - } \\
3.6 \%\end{array}$ & $\begin{array}{l}\cdot \text { NCLEX-RN } \\
\text { pass: } 94 \%- \\
100 \%\end{array}$ & $\begin{array}{l}\text { Staff RN } \\
\text { performance } \\
\text { criteria: }^{\text {b }} \\
\text { graduates: } \\
2.05 / 5.00, \\
\text { managers: } \\
1.88 / 5.00\end{array}$ & \\
\hline $\begin{array}{l}\text { Shatto et al. } \\
\text { (2016), United } \\
\text { States }\end{array}$ & $\begin{array}{l}\text { To explore the } \\
\text { experience of the } \\
\text { AMSN graduate's } \\
\text { transition to } \\
\text { practice over time }\end{array}$ & $\begin{array}{l}\text { Descriptive } \\
\text { study } \\
\text { (4 time } \\
\text { surveyed) }\end{array}$ & $\begin{array}{l}\text { AMSN } \\
\text { graduates } \\
(n=8)\end{array}$ & $\begin{array}{l}\text { Satisfaction at } \\
\text { graduation: } \\
100 \%\end{array}$ & $\begin{array}{l}\text { Preparation for } \\
\text { nursing career } \\
\text { (at graduation): } \\
100 \%\end{array}$ & $\begin{array}{l}\text { Nursing career } \\
\text { satisfaction (at } \\
\text { 1-year } \\
\text { postgraduation): } \\
93.4 \%\end{array}$ & \\
\hline $\begin{array}{l}\text { Cantlay et al. } \\
(2017), \\
\text { Australia }\end{array}$ & $\begin{array}{l}\text { To assess the } \\
\text { efficacy of the } \\
\text { AMSN program } \\
\text { based on } \\
\text { graduates' }\end{array}$ & $\begin{array}{l}\text { Descriptive } \\
\text { study }\end{array}$ & $\begin{array}{l}\text { AMSN } \\
\text { graduates } \\
(n=49)\end{array}$ & & $\begin{array}{l}\text { - GPA: } 82 \% \geq 3.0 \\
\text { - Employment: } \\
98 \%\end{array}$ & $\begin{array}{l}\text { Nursing career } \\
\text { satisfaction: } \\
86 \%\end{array}$ & \\
\hline
\end{tabular}




\begin{tabular}{|l|l|l|l|l|}
\hline & $\begin{array}{l}\text { practice } \\
\text { preparedness }\end{array}$ & & & $\begin{array}{l}\text { Preparation for } \\
\text { practitioner: } \\
71 \%\end{array}$ \\
\hline
\end{tabular}

Note. All GPAs are converted to a 4.0 scale. AMSN = accelerated Master of Science in Nursing; GPA = grade point average; NCLEX-RN= National Council Licensing Examination for Registered Nurses.

${ }^{a}$ No data for Level 4.

${ }^{b}$ Scored on a 5-point scale $(1=$ extremely effective, 2 = very effective, $3=$ somewhat effective, $4=$ not very effective, $5=$ not at all effective $)$. 